Diabetologia 7, 118-124 (1971)

(C) by Springer-Verlag 1971

\title{
Treatment of Malignant Insulinoma with Streptozotocin*
}

\author{
C.K. Smith, R.W. Stoll, J. Vance, H. Ricketts, and R. H. Williays \\ Departments of Medicine and Radiology, School of Medicine, University of Washington, Washington, D.C., USA
}

Received: November 5, 1970, accepted: December 17, 1970

\begin{abstract}
Summary. Two patients with malignant insulinoma and hepatic metastases were treated with streptozotocin, administered directly into the celiac artery. Decreases in tumor size were documented radiographically. One patient was in a terminal state when first treated, but the other patient was in moderately good general health and responded well. Some side-effects, including renal tubular damage, were observed but were relatively minor. Streptozotocin therapy offers some benefit in patients with malignant insulinoma.
\end{abstract}

Traitement de l'insulinome malin par la streptozotocine Résumé. Deux patients atteints d'insulinome avec métastases hépatiques ont été traités par injection de streptozotocine dans l'artère coeliaque. Une diminution des dimensions de la tumeur a été mise en évidence radiologiquement. $L^{\prime}$ un des patients était dans un état terminal au moment où le traitement a été institué; l'autre patient dont l'état général était relativement bon a bien répondu à la thérapeutique. Certains effets collatéraux dont des signes d'atteinte rénale tubulaire, ont été notés mais sont relativement peu importants. La streptozotocine offre donc un certain interêt dans le traitement de l'insulinome malin. zotocin

Die Behandlung des malignen Insulinoms mit Strepto-

Zusammenfassung. Zwei Patienten mit metastasierendem Insulinom wurde Streptozotozin in die Arteria coeliaca verabreicht. Daraufhin ließ sich radiographisch ein Rückgang' der Tumorgröße nachweisen. Bei Therapiebeginn befand sich ein Patient in mäßigem, der andere in sehr schlechtem Allgemeinzustand. Einige Nebenwirkungen, insbesondere Schädigung der Nierentubuli, traten auf, waren aber von geringem Ausmaß. Streptozotozin ist geeignet, Patienten, die an einem malignen Insulinom leiden, Linderung zu verschaffen.

Key-words: Insulinoma, malignant, streptozotocin, and celiac artery.

\section{Introduction}

Total resection of malignant insulinoma tissue is not feasible. Such patients die usually from intractable hypoglycemia or direct tumour invasion. While hypoglycaemia is often controlled with diazoxide, invasion by the tumours progresses. However, streptozotocin (N-nitroso-urea, derivative of glucosamine) has recently been used as a potent betacytotoxic agent, and we are reporting our experiences with it in two patients.

Case 1. A 60-year-old white male was in good health until September, 1967, when he suddenly began having severe hypoglycaemic spells, often associated with coma. In late September laparotomy revealed numerous large malignant insulinoma lesions in the pancreas and liver, and only biopsy specimens were removed. Despite $400 \mathrm{mg}$ of diazoxide every $6 \mathrm{~h}$, constant intravenous infusion of $20 \%$ glucose, and $100 \mathrm{mg}$ prednisolone daily, many severe hypoglycaemic reactions occurred, often with seizures and coma. He also developed marked congestive heart failure, with oedema and ascites, which persisted despite digitalization and vigorous diuretic therapy. Some of the medications

* Supported by grants (AM 05020 and AM 02456) from the United States Public Health Service. A portion of this work was conducted through the Clinical Research Center of the University of Washington supported by the NIH. (Grant RR-37). (Dr. Stoll is the recipient of Special Fellowship 5 F3 AM 37, 832). used after his admission to the University Hospital (Dec. 27) and their correlation with hypoglycaemic symptoms and urine glucose levels are summarized in Fig. 1 A. Numerous laboratory studies were performed during this hospitalization. The haemoglobin varied from 10.0 to $12.5 \mathrm{~g} / 100 \mathrm{ml}$, the white blood cell count ranged from 6900 to $15500 / \mathrm{mm}^{3}$, and the platelets from 200000 to $400000 / \mathrm{mm}^{3}$. Blood urea nitrogen and serum creatinine remained normal throughout the hospital course. Bilirubin remained less than $0.6 \mathrm{mg} / 100$ $\mathrm{ml}$. After streptozotocin treatment, SGOT and SGPT rose transiently and a slightly high level of alkaline phosphatase increased to $20 \mathrm{King}$-Armstrong units. The serum sodium, potassium, and chloride decreased with worsening of his clinical condition, but returned to normal with fluid and electrolyte therapy. The bicarbonate level was normal. Serial chest films showed progressive pulmonary congestion. Skull films were normal.

On December 28, $3.8 \mathrm{~g}$ of streptozotocin in $350 \mathrm{cc}$ of distilled water was given over one hour into a catheter placed in the celiac artery. However, the catheter apparently slipped back into the aorta during this injection. Therefore, Celiac arteriograms were not of good quality. There was no major change in the clinical state or in the hypoglycaemia, and on December $29,2.5 \mathrm{~g}$ of streptozotocin in $230 \mathrm{ml}$ distilled water was given into the celiac artery within $15 \mathrm{~min}$. This dose was repeated 
over the next 30 minutes. After waiting one hour, another $4 \mathrm{~g}$ was given over 15 minutes, for a total dose of $9 \mathrm{~g}$ within $2.5 \mathrm{~h}$. This was followed by ileus which responded to conservative medical therapy. (Serum $\mathrm{Ca}^{++}$decreased from $8.6 \mathrm{mg}$ to $7 \mathrm{mg} / 100 \mathrm{ml}$ and phosphorus from $3 \mathrm{mg}$ to $1.3 \mathrm{mg} / 100 \mathrm{ml}$ ). About 5 days after these treatments, definite improvement occurred. As illustrated in Figure $1 \mathrm{~A}$, from January 2-7, no hypoglycaemic symptoms developed despite cessation partially controlled his hypoglycaemia ; his heart failure became worse, and he died on January 26, 1968.

Autopsy revealed a malignant insulinoma in the tail of the pancreas with multiple metastatic nodules in the liver; infarction in the left caudate nucleus; severe general atherosclerosis, including the coronary arteries and thrombosis of the right coronary. By light microscopy, pancreatic islets showed no evidence of damage by streptozotocin.

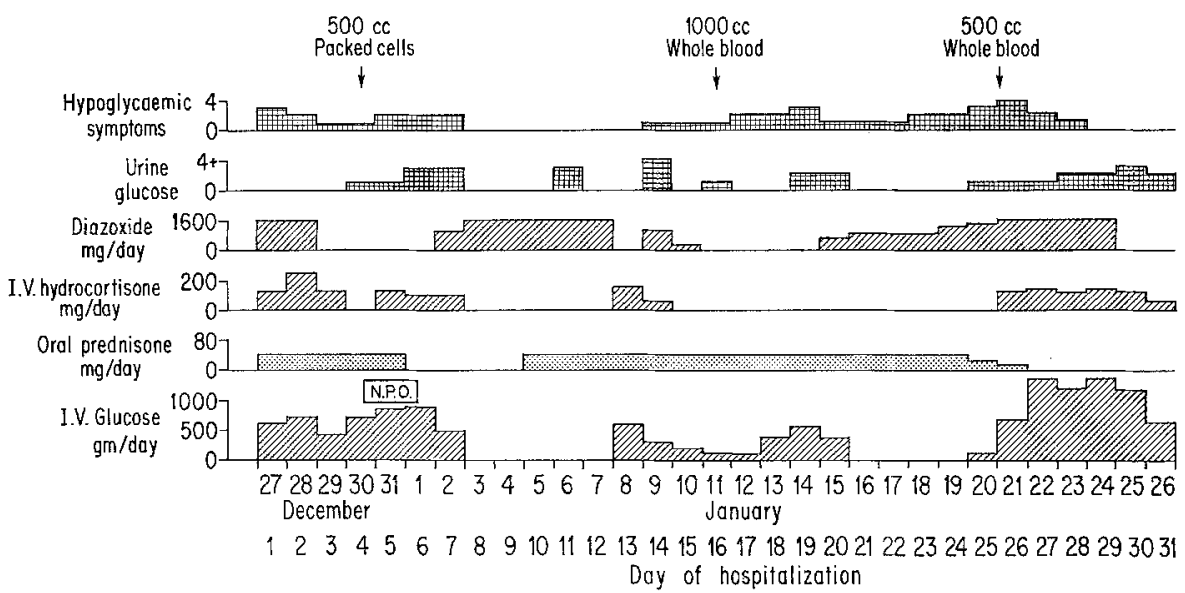

Fig. 1. A. Laboratory and clinical data on case \#1. Hypoglycaemic symptoms have been arbitrarily graded $1+$ to $4+$

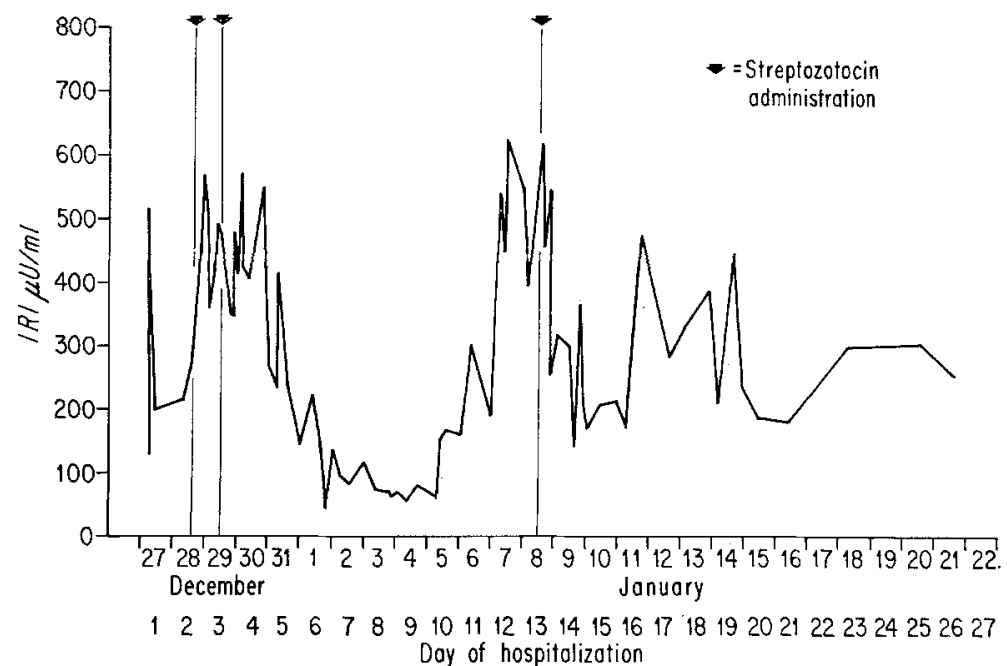

Fig. 1B. IRI levels in relation to streptozotocin treatment in case \#1

of glucose infusion, and periodic omission of glucosteroids, and diazoxide. As seen in Figure 1 B, plasma insulin levels were lower during this interval. On January 8, streptozotocin was infused in the celiac artery: $12 \mathrm{~g}$ in $460 \mathrm{cc}$ of water within $15 \mathrm{~min}$, and beginning twenty minutes later, $5 \mathrm{~g}$ in $180 \mathrm{ml}$ water within $40 \mathrm{~min}$, making a total of $29.8 \mathrm{~g}$ during the hospital stay. Five hours after the infusion, the patient had two hypoglycaemic seizures despite constant administration of $10 \%$ glucose. Further therapy only
Case 2. E.H., aged 25, had had hypoglycaemia periodically, as one phase of her multiple endocrine adenomatoses [26]. When two-thirds of her pancreas was removed at age 6 (1951), general beta cell hyperplasia was found. For several months following surgery, the hypoglycaemic attacks were severe, requiring steroid therapy for 9 months, but they then abated for several years. Recurrent attacks led to re-exploration at age 11 . A $1 \times 2 \mathrm{~cm}$ beta cell adenoma was removed from the head of the pancreas. No metastases were noted by the 
surgeon. No other hypoglycaemic symptoms appeared until age 20 , when they appeared often and were severe. An infiltrating beta cell carcinoma was incompletely removed from the pancreatic remnant. Several metastatic nodules were seen in the liver, which histologically were beta cell carcinoma. Thus, apparently from age 6 to 20 there were transitions: islet cell hyperplasia $\rightarrow$ adenoma $\rightarrow$ carcinoma. Shortly after this operation, diazoxide therapy was instituted and

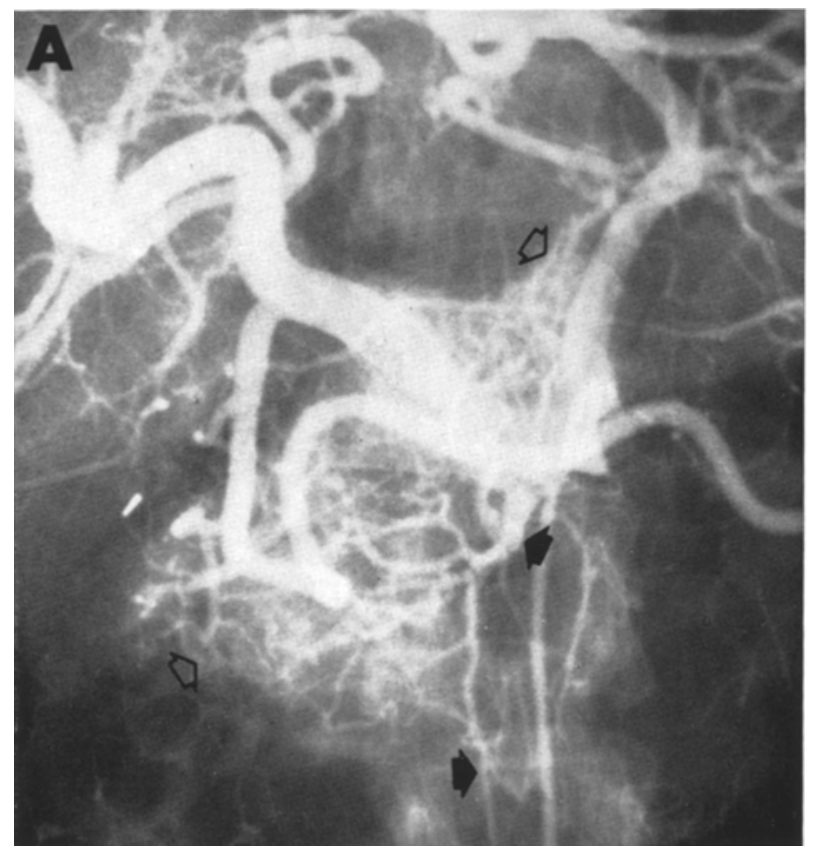

Fig. 2A. July 10, 1969, immediately prior to the first selective arterial infusion; a celiac arteriogram shows a large hypervascular mass involving the head of the pancreas and extending superiorly and laterally to the left along the course of the remaining pancreatic tissue (open arrows). A prominent dorsal pancreatic artery is a major supply to the tumour and gives off retroperitoneal branches supplying of the tumour along the aorta (closed arrows)

has been given almost continually for the last 5 years. Hypoglycaemia was infrequent until 1969 , but it then became severe in spite of $1600 \mathrm{mg}$ of diazoxide per day. In July, 1969, she was admitted for her first course of streptozotocin. She was alert and coöperative, but was obese and had virilization from hyperadrenal activity for more than 15 years. Haematologic indices, electrolytes, BUN, creatinine, alkaline phosphatase, SGOT, SGPT, bilirubin and proteins were all normal. There was $6 \%$ BSP retention at $45 \mathrm{~min}$. Chest film and a liver scan were normal.

On July 10, 1969, a celiac arteriogram showed a large tumour mass in the area of the pancreas (Fig. $2 \mathrm{~A}$, $2 \mathrm{~B})$. Two grams of streptozotocin in $200 \mathrm{ml}$ saline was given into the celiac artery over $40 \mathrm{~min}$. No renal, haepatic, haematologic or other toxicity was noted over the next five days. On July 15th, $4 \mathrm{~g}$ of streptozotocin in $1 \mathrm{I}$ of saline was given into an antecubital vein over $45 \mathrm{~min}$. This was followed by a mild fever and a slight rise in the alkaline phosphatase, SGOT and SGPT. She tolerated the treatments well, but hypoglycaemic symptoms persisted in spite of diazoxide, $800 \mathrm{mg}$ daily. On August 6, a celiac arteriogram showed that the tumour size and vascularity were significantly reduced (Fig. $3 \mathrm{~A}, 3 \mathrm{~B}$ ). Five grams of streptozotocin, in $600 \mathrm{ml}$ saline, was given into the celiac artery over $15 \mathrm{~min}$. A tran-

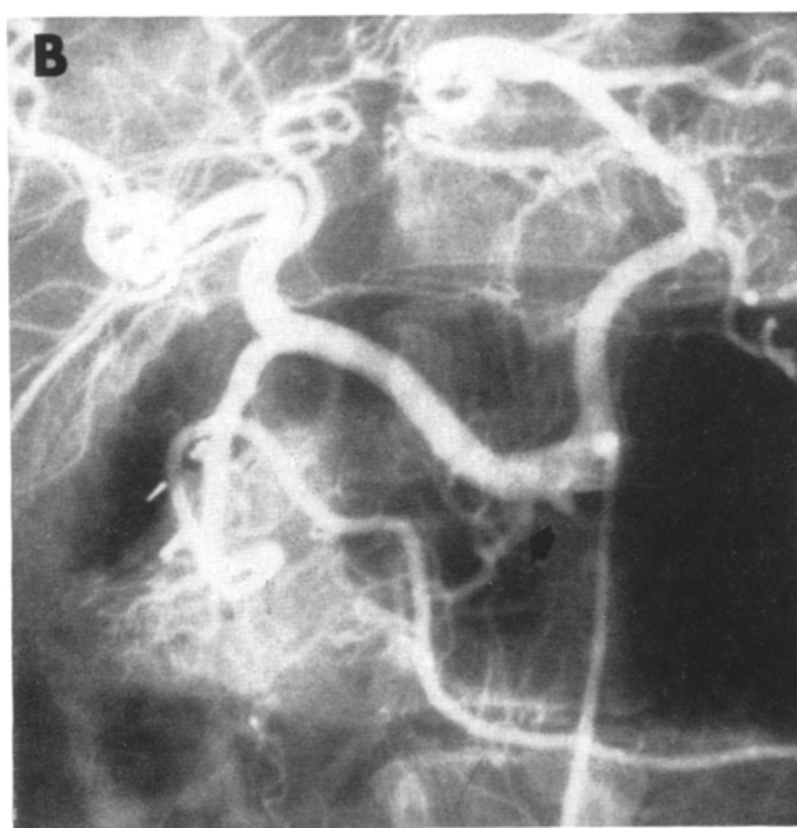

Fig. 2B. August 6, 1968. At the time of the second infusion there is marked reduction in tumour size and vascularity, particularly in its superior and inferior extensions

sient increase in SGOT, SGPT, and a transient decrease in the neutrophil and platelet counts followed. She developed an alkaline urine, mild systemic acidosis, and hypokalaemia consistent with mild renal tubular acidosis. On August 21, she was discharged from the hospital still requiring diazoxide. Upon readmission, September 9 , a celiac arteriogram showed slight further shrinkage of the neoplasm. Four grams of streptozotocin in $500 \mathrm{ml}$ of saline was given into the celiac artery over $20 \mathrm{~min}$. A temperature spike to 103 degrees was noted during the infusion. Blood cultures were sterile. Three hours later, severe hypoglycaemia with a seizure developed, requiring intravenous glucose. In the next four days, her blood glucose returned to physiologic levels. Transient metabolic acidosis with an alkaline urine was again noted, as was a rise in liver enzymes and a transient fall in the platelet count. Table 1 shows sequential changes in selected laboratory parameters during this treatment period.

Her last course of streptozotocin treatment was on December 5, 1969. The celiae arteriogram showed only 
slight further shrinkage of the tumour (Fig. 4A, 4B), and she was given $6 \mathrm{~g}$ of streptozotocin in the celiac artery over $25 \mathrm{~min}$. On this occasion, she was also given a glucose load because of a suggestion that hyperglycaemia enhanced streptozotocin damage in animals [5]. Again renal tubular acidosis developed. Further tubular defects with losses of potassium, uric acid, glucose (in spite of low blood glucoses) and increased because of severe hypoglycaemia. The second set of values was obtained on July 22, 1969, after receiving $6 \mathrm{~g}$ of streptozotocin. The third set of values was obtained on Nov. 26, 1969, after receiving 9 additional grams of streptozotocin. Tolbutamide induces much less insulin responsiveness after streptozotocin treatment, indicating that neither normal nor abnormal islet tissue is responding. A test on Jan. 9, 1970, after
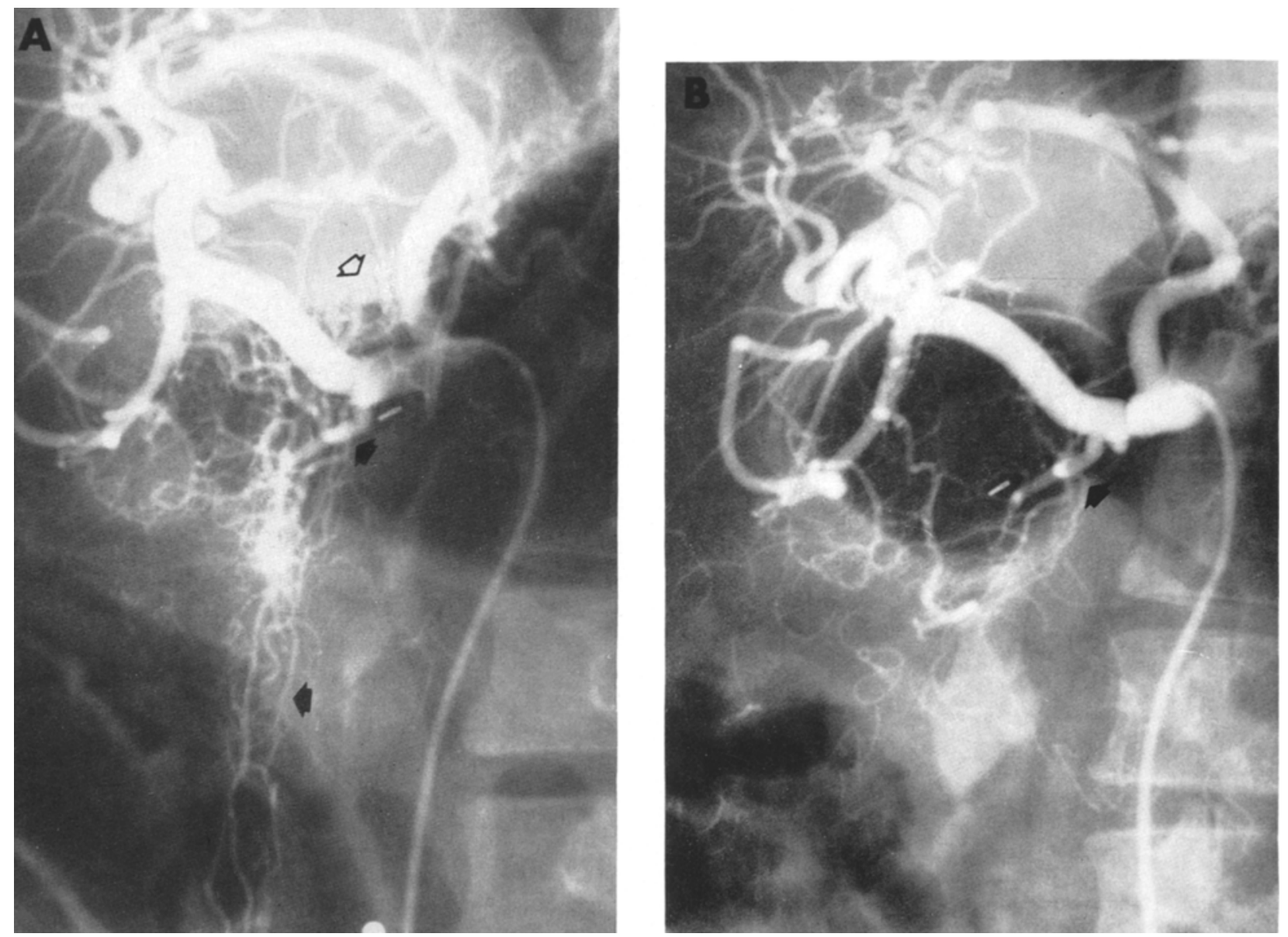

Fig. 3. Oblique views from the same examinations in July (A) and August (B) illustrate the marked reduction in tumour vascularity along the aorta

levels of cysteine were also noted. She also developed mild nephrogenic diabetes insipidus, refractory to vasopressin infusion. All these changes have persisted. to some degree. She also developed acanthocytosis demonstrated 4 days after treatment; 2 days later, it was much less apparent. Fig. 6 shows selected values for insulin and glucose from sequential tolbutamide tolerance tests before, during, and after her last treatment with streptozotocin. The first test (Jan. 6, 1969) was performed while the patient was treated with diazoxide, which explains the relatively small drop in the blood glucose values. A test was performed after discontinuing diazoxide, but had to be terminated another $6 \mathrm{~g}$, was similar except for slightly lower values The patient has been rehabilitated and has been discharged from a nursing home to work at a regular job.

\section{Discussion}

With islet cell tumours, survival is longer than with exocrine tumours of the pancreas, but exact figures are hard to assess because of difficulties in histological classification. Kernen et al. [13] reviewed the course of patients with islet cell carcinoma, malignant by virtue of metastases or aggressive infiltrative growth into the 
surrounding tissue. Sixteen patients survived for at least three years after the pathological diagnosis was made, and one patient was alive 13 years after biopsy of hepatic metastases. Five patients had documented hyperinsulinism. Thus, metastatic disease with or without hyperinsulinism is compatible with long survival, a fact which must be considered in evaluating treatment. changes in the size of hepatic metastases were demonstrated angiographically and by liver scanning [25].

However, when there are distant metastases, treatment is very difficult and mortality results from local tumour invasion, secretion of other hormones [14-15] or hypoglycaemia due to excessive insulin secretion.

Symptomatic treatment of hypoglycaemia has included frequent feedings, steroids, glucagon, and diaz-
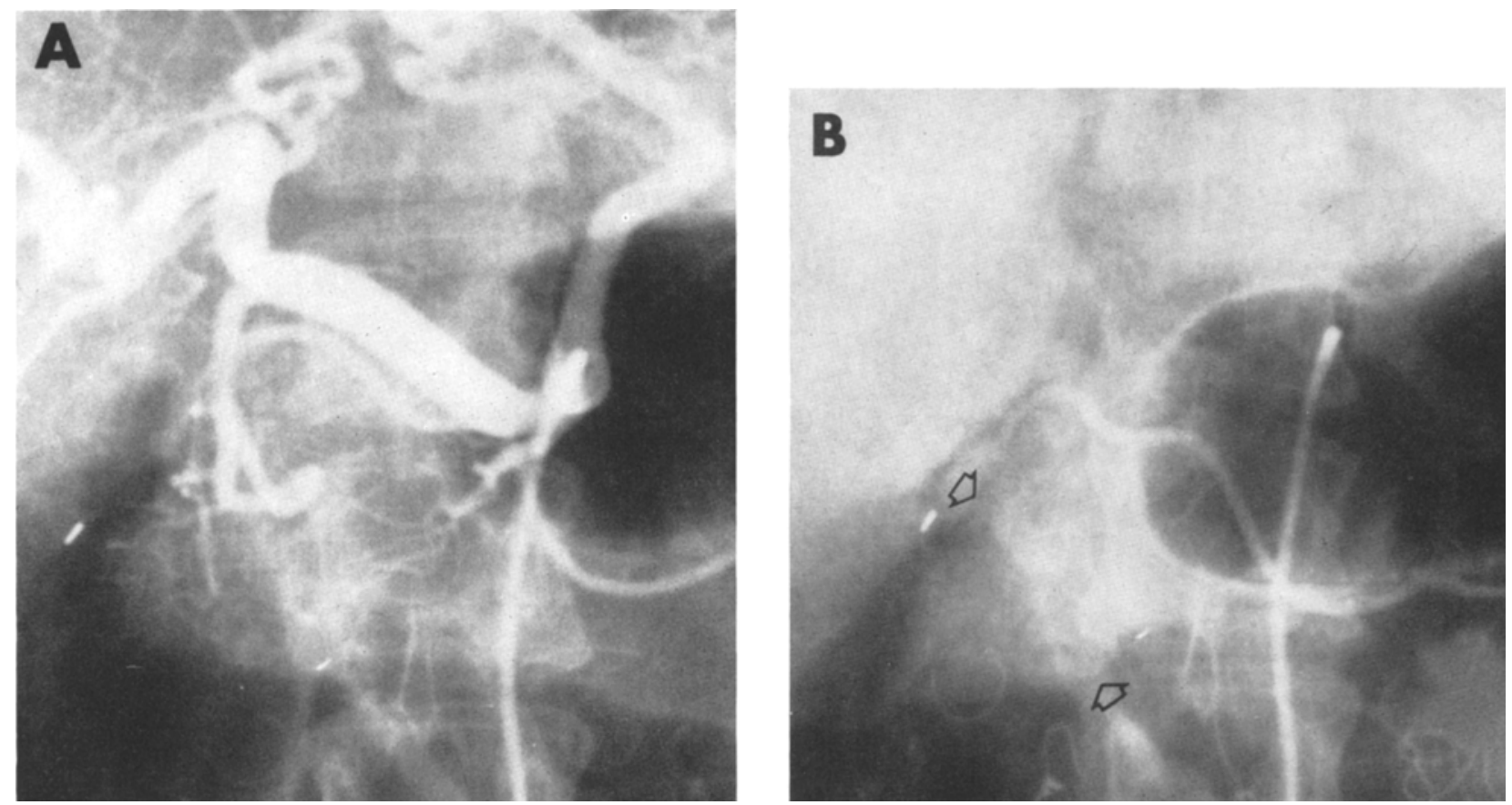

Fig. 4. December 5, 1969. Angiographic examination at the time of the fourth selective infusion shows some further decrease in the size and number of tumour vessels (A) and the tumour mass (B)

Surgery is indicated when total extirpation of the neoplasm seems feasible. Angiographic studies often aid in localization of the tumours $[7,4,21,19]$. For example, with it lesions were detected in 33 of 45 patients. In four, the process was malignant and in two of these, hepatic metastases were shown to be hypervascular. Although considerable variability in the histologic vascular pattern of these tumours has been described, most lesions are detected angiographically by a prolonged parenchymal "blush" produced by an increased number of venous sinusoids in which contrastladen blood pools for $6-8$ sec following injection. In malignant lesions a pattern of tortuous and disorganized vessels are seen, as in our second patient in whom dense opacification of the primary tumour bed provided an index of tumour size which could be followed throughout the patient's course. The detection of change in tumour size by the vascular pattern following selective intra-arterial administration of a chemotherapeutic agent has been reported in a case of malignant insulinoma treated with 5-fluorouracil. In that report,
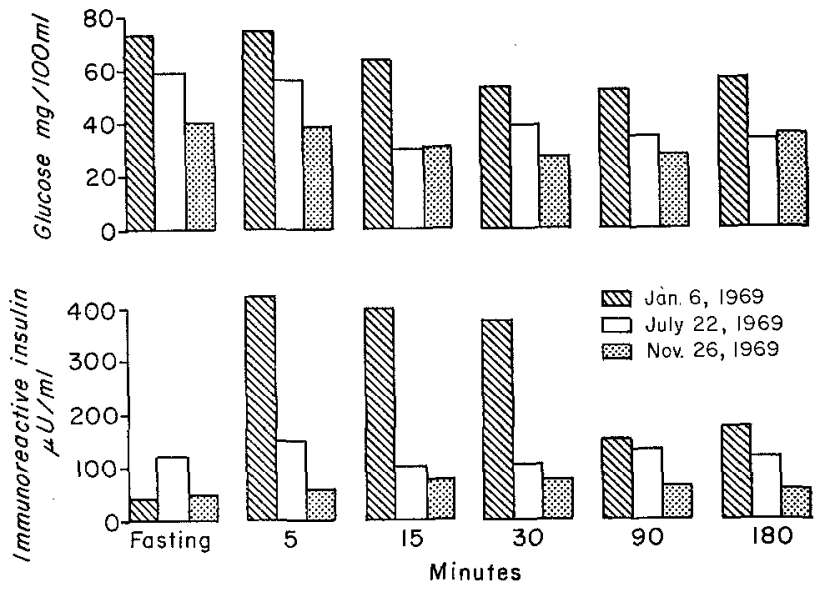

$\square$ Jàn 6,1969
$\square$ July 22,1969 Nov. 26, 1969

Fig. 6. Insulin and glucose values from serial tolbutamide tolerance tests. - There is marked a decrease in the insulin output induced by tolbutamide between January and July and a further, less striking decrease in November. The low values for glucose in November can be partly accounted for by renal glycosuria which was due to streptozotocininduced tubular damage 
oxide. Diazoxide is a nondiuretic benzothiadiazine that decreases the level of circulating insulin possibly by increasing catecholamines [10], although it may have extrapancreatic effects [8]. Tumourcidal agents such as alloxan [18] and nitrogen mustard [9] have not been sufficiently effective. There is a brief report [17] of one patient with insulinoma treated for 16 months with Tubercidin, with no evidence of recurrence, and another responding to 5-fluorouracil [25]. malignant insulinoma were treated by Sadoff [22]. One had received several types of antitumour chemotherapy without benefit. Following administration of streptozotocin into the aorta above the celiac axis ( $1 \mathrm{~g}$ daily for 10 days), renal tubular acidosis and "dehydration with prerenal azotemia" developed. Treatment in this manner can be expected to produce a high concentration of streptozotocin in the kidneys, and associated renal damage. Unless the drug can be given directly

Table 1. Changes in selected laboratory parameters of case \# 2 during treatment with streptozotocin

\begin{tabular}{|c|c|c|c|c|c|c|c|c|c|c|}
\hline Date & $\begin{array}{l}\text { Potas- } \\
\text { sium } \\
\text { ( } \mathrm{mEq} / \\
\text { litre) }\end{array}$ & $\begin{array}{l}\text { Bicar- } \\
\text { bonate } \\
\text { (mEq/ } \\
\text { litre) }\end{array}$ & $\begin{array}{l}\text { Uric } \\
\text { Acid } \\
(\mathrm{mg} / \\
100 \mathrm{ml})\end{array}$ & $\begin{array}{l}\text { Cal- } \\
\text { ciuma } \\
(\mathrm{mg} / \\
\mathbf{1 0 0} \mathrm{ml})\end{array}$ & $\begin{array}{l}\text { Alka- } \\
\text { linea } \\
\text { Phos- } \\
\text { phatase }\end{array}$ & $\begin{array}{l}\text { SGPT } \\
\text { units }\end{array}$ & $\begin{array}{l}\text { White } \\
\text { blood cell } \\
\text { count } \\
(\text { cells/ } \\
\text { mm }^{3} \text { ) }\end{array}$ & $\begin{array}{l}\text { Neuro- } \\
\text { phils } \\
\text { (cells/ } \\
\mathrm{mm}^{3} \text { ) }\end{array}$ & $\begin{array}{l}\text { Eosino- } \\
\text { phils } \\
\text { (cells/ } \\
\text { mm }^{3} \text { ) }\end{array}$ & $\begin{array}{l}\text { Platelet } \\
\text { count } \\
\left(\text { cells } / \mathrm{mm}^{3}\right)\end{array}$ \\
\hline $9 / 8 / 69$ & 4.0 & 23 & 4.1 & 11.0 & 80 & 15 & 10500 & 7100 & 300 & 452000 \\
\hline $\begin{array}{l}9 / 2 / 69 \\
9 / 11 / 69\end{array}$ & $\begin{array}{l}4.0 \mathrm{~g} 0 \\
3.4\end{array}$ & $\begin{array}{l}\text { streptozo } \\
20\end{array}$ & $\begin{array}{l}\text { ocin into } \\
2.4\end{array}$ & $\begin{array}{c}\text { celiac art } \\
9.4\end{array}$ & ${ }_{86}^{e r y}$ & 53 & & & & \\
\hline $9 / 13 / 69$ & 3.2 & 17 & & & 156 & 42 & 7700 & 4400 & 1400 & 173000 \\
\hline $9 / 15 / 69$ & 3.8 & 22 & 2.3 & 11.0 & 126 & 24 & 8400 & 3500 & 860 & 320000 \\
\hline
\end{tabular}

a International units - normal up to 90 .

Streptozotocin, a broad spectrum antibiotic, has been shown to be cytotoxic in a number of animal tumours, but has appeared more specific for the pancreatic $\beta$-cell $[12,2]$. Therefore, it has been used frequently as an experimental diabetogenic agent. In rats and mice, there is a triphasic response of the blood sugar, with an initial hyperglycaemia phase followed by hypoglycaemia associated with excessive release of insulin from necrotic beta cells, and then permanent diabetes $[12$, 23]. Since nicotinamide but not nicotinic acid, given prior to streptozotocin administration diminishes its diabetogenic effect, it has been suggested that streptozotocin interferes with NAD (nicotinic adenine dinucleotide) production in the beta cell $[24,6]$.

Streptozotocin has cytopathic effects in several organs. In rats, it has caused tumours of the kidney and pancreas [1], focal hepatic necrosis [12], cataracts, accumulation of glycogen in the proximal tubules and damage to pancreatic exocrine cells [11]. Hepatic toxicity is also seen in other animals, whereas there tends to be sparing of the bone marrow and gastrointestinal mucosa [16].

The first patient treated with streptozotocin was a lady with malignant insulinoma [20], who was given $8.5 \mathrm{~g}$ intravenously in three separate doses over six weeks. There was a fall in the serum insulin, with improvement of symptoms and weight gain over a fourmonth followup. There was no mention of kidney or liver toxicity. A man with a malignant insulinoma was treated with a total $4.5 \mathrm{~g}$ of streptozotocin intravenously in 2 divided doses over two weeks, with symptomatic improvement and a decrease in liver size [3]. A four-month followup was given but there was no report of toxicity. Finally, two patients with into the celiac artery without evidence of regurgitation into the arta, it is desirable to infuse it into a peripheral vein. Sadoff's second patient, not described in detail, received $10 \mathrm{~g}$ of streptozotocin intra-arterially and developed renal glycosuria, renal tubular acidosis and necrosis with complete renal shutdown.

Although the maximum dose tolerated by man is much higher than in experimental animals, some toxicity has been noted in the few patients treated, including a rise in liver enzymes, mild leukopenia, eosinophilia and thrombocytopenia. Our second patient developed renal tubular acidoses. Two previously undescribed reactions were seen in this case : (a) nephrogenic diabetes insipidus, with polyuria persisting but of a mild degree after one month, and (b) marked acanthocytosis, seen in the peripheral blood smear. The pathogenesis of this change is unknown although it could have resulted from interference with red cell NAD levels.

In conclusion, recognition of the undesirable effects of streptozotocin must be considered, but it would appear to offer relatively greater effectiveness in treating malignant insulinomas than do other current therapies. It seems logical to initiate this treatment before the patient is desperately ill, and to administer streptozotocin directly into the celiac artery, permitting the most concentrated exposure to the tumour and less to the kidneys. Although each of our patients received significant doses, and although renal tubular damage was noted, it did not produce azotaemia or marked deterioration of renal function. Also, as in our second patient, changes in the size of the tumour can be followed angiographically and correlated with clinical improvement. 


\section{References}

1. Arison, R.N., Feudale, E.L.: Induction of renal tumors by streptozotocin in rats. Nature 214, 1254$1255(1967)$.

2. Arison, R.N., Ciaccio, E.I., Glitzer, M.S., Cassaro, J. A., Pruss, M.P.: Light and electron microscopy of lesions in rats rendered diabetic with streptozotocin. Diabetes 16, $51-56(1967)$.

3. Arnould, Y., Ooms, H.A., Bastenie, P.A.: Treatment of insulinoma with streptozotocin. Lancet 1969 I, 1210-1211.

4. Bookstein, J.J., Oberman, H.A.: Appraisal of selective angiography in localizing islet-cell tumors of the pancreas. Radiology 86, 682-685 (1966).

5. Brosky, G., Logothetopoulas, J.: Streptozotocin diabetes in the mouse and guinea pig. Diabetes 18, 606611 (1969).

6. Dulin, W.E., Wyse, B.M.: Studies on the ability of compounds to block the diabetogenic activity of streptozotocin. Diabetes 18, 459-466 (1969).

7. Epstein, H. Y., Abrams, R.M., Beranbaum, E. R., Localio, S. A. : Angiographic localization of insulinomas: high reported success rate and two additional cases. Ann. Surg. 169, 349--354 (1969).

8. Fajans, S.S., Floyd, J.C., Thiffault, C.A., Knopf, R. F., Harrison, T.S., Conn, J.W.: Further studies on diazoxide suppression of insulin release from abnormal and normal islet tissue in man. Ann. N.Y. Acad. Sci. 150, $261-280$ (1968).

9. Fonkalsrud, E. W., Dilley, R.B., Longmire, W.P.: Insulin secreting tumors of the pancreas. Ann. Surg. 159, $730-741$ (1964).

10. Graber, A.L., Porte, D., Williams, R.H.: Clinical use of diazoxide and studies of the mechanism of its hyperglycemic effects in man. Ann. N.Y. Acad. Sci. 150, 303-308 (1968).

11. Herr, R.R., Eble, T.E., Borgy, M.E., Jahnke, H.K.: Isolation and characterization of streptozotocin. Antibiotics Annual p. 236-240 (1959-60).

12. Junod, A., Lambert, A.E., Orci, L.L., Pictet, R., Gonet, A.E., Renold, A.E.: Studies of the diabetogenic action of streptozotocin. Proc. Soc. exp. biol. Med. 126, 201-205 (1967).

13. Kernen, J.A., Scofield, G., Koucky, C., Beniter, R.E., Ackerman, L.V.: Long survival with islet cell carcinoma of the pancreas. Amer. J. Clin. Path. 39, $137-$ 147 (1963).

14. Law, D.H., Liddle, G.W., Scott, H.W., Tauber, S.D.: Ectopic production of multiple hormones (ACTH, MSH, and Gastrin) by a single malignant tumor. New Engl. J. Med. 273, 292-296 (1965).
15. Levin, M.: Endocrine syndromes associated with pancreatic islet cell tumors. Med. Clin. N. Amer. 52, 295312 (1968).

16. Livingston, R.B., Carter, S.K.: Streptozotocin (NSC85998) chemotherapy fact sheet program analysis branch, Chemotherapy, National Cancer Institute, August (1969).

17. Longmire, W.P., Brown, J., Buckberg, G.D., Cooke, A., Glober, G., Hanafee, W.N., Kantor, G., Matsumoto, K. K., Plested, W.G., Rochlin, D.B., Wilkerson, J.A.: Istet cell tumors of the pancreas. Ann. intern. Med. 68, 203-221 (1968).

18. Lukens, F.D.W.: Alloxan diabetes. Physiol. Rev. 28, $304-330(1948)$.

19. Madsen, B.: Damonstration of pancreatic insulomas by angiography. Brit. J. Radiol. 39, 488-493 (1965).

20. Murray-Lyon, I.M., Brown, M., Hogbin, B.M., Bennell, A., Edwards, J.C., Taylor, K.W.: Treatment of multiple hormone producing malignant islet tumor with streptozotocin. Lancet $1968 \mathrm{II}, 895-898$.

21. Nebesar, R.A., Pollard, J.J.: A critical evaluation of selective celiac and superior mesenteric angiography in the diagnosis of pancreatic diseases, particularly malignant tumor: facts and "artefacts." Radiology 89, 1017-1027 (1967).

22. Sadoff, H.: Effects of streptozotocin in a patient with islet cell carcinoma. Diabetes 18, 675-678 (1969).

23. Schein, P.S., Bates, R.W.: Plasma glucose levels in normal and adrenalectomized mice treated with streptozotocin and nicotinamide. Diabetes 17, 760$765(1968)$

24. Schein, P.S., Cooney, D.A., Vernon, M.L.: The use of nicotinamide to modify the toxicity of streptozotocin diabetes without loss of antitumor activity. Cancer Res. 27, $2324-2331$ (1967).

25. Thomas, R.L., Robinson, A.E., Johnsrude, I.S. Goodrich, J.K., Lester, R.G.: The demonstration of an insulin and gastrin producing pancreatic tumor by angiography and pancreatic scanning. Amer. J. Roent. 104, 646-651 (1968).

26. Vance, J.E., Stoll, R.W., Kitabchi, A.E., Williams, R.H., Wood, F.C.: Nesidioblastosis in familial endocrine adenomatosis. JAMA 207, 1679-1682 (1969).

R.H. Williams, M.D.

Dept. of Medicine

Division of Endocrinology

University of Washington

Seattle, Washington 98105

USA 